\title{
"BROKER OR BRAKEMAN?": AN ANALYSIS OF PARLIAMENTARY DEBATES ON SCHUMAN PLAN BETWEEN BRITISH LABOUR AND CONSERVATIVE PARTIES*
}

\author{
Pınar UZ HANÇARLI **
}

\begin{abstract}
9 May 1950 was a milestone in the history of European Integration when the French Foreign Minister Robert Schuman proposed the pooling of French and West German supplies of coal and steel; and made an invitation to other European states willing to be involved in this plan. The invitation for the conference on Schuman Plan came to the agenda of British Parliament on 26 June as a motion by Conservative Party demanding Labour Party Government to accept the invitation which had already been declined at the end of May, 1950. Following the debate on 2627 June, The Economist published an article titled "Broker or Brakeman?" in which the Schuman Plan discussions on British Parliament were explored. The Journal was arguing that "it is the resemblances, not the differences, between the outlook of Government and Opposition that are most striking" on this issue of foreign policy. Although this argument makes sense to a certain extent; this study argues that it was the adversarial nature of British party politics that shaped the general structure of the above mentioned parliamentary debate. Moreover, this nature contributed the decision makers to apply exceptionalist discourses and policies when it came to European Integration, therefore to a British non-involvement in the Plan.
\end{abstract}

Key Words: Schuman Plan, British Conservative Party, British Labour Party, adversarialism, exceptionalism.

\section{$\ddot{\mathbf{O z}}$}

Fransız Dışişleri Bakanı Robert Schuman'ın Fransa ve Batı Almanya'nın kömür ve çelik rezervlerinin birleştirilmesini önermesi ve diğer Avrupa devletlerine de bu plana katılmaları için davet göndermesi ile 9 Mayıs 1950 Avrupa bütünleşmesi tarihinde bir dönüm noktası oldu. Aslında 1950 Mayıs'ının sonunda Britanya tarafından reddedilen Schuman Planı için düzenlenecek konferansa katılım daveti Britanya Parlamentosu gündemine 26 Haziran'da Muhafazakâr Parti'nin İşçi Partisi hükümetinin bu daveti kabulünü talep eden önergesiyle gelmiş

\footnotetext{
* This study is an extended version of the presentation given in 11th Annual Conference of Graduate Centre for Europe, University of Birmingham, United Kingdom on 11-12 May, 2017.

** Research Assistant, Department of Political Science and Public Administration, Pamukkale University, Denizli. E-mail: puz@pau.edu.tr
} 
oldu. 26-27 Haziran'daki parlamento görüşmelerinin ardından The Economist dergisi bu görüşmelerin ele alındığı "Simsar mı Frenci mi?" başlık bir makale yayınladı. Makaleye göre bu dış politika konusunda "Muhalefet ve İktidar tutumları arasında belirgin olan görüş farklılıkları değil, benzerlikleriydi”. Her ne kadar bu argüman belirli bir dereceye kadar anlaşılabilir olsa da, bu çalışmada Britanya siyasi partilerinin hasımlığa dayanan yapısının yukarıda bahsi geçen parlamento görüşmelerinin genel çerçevesini belirlediği savunulmaktadır. Ayrıca, bu siyasi yapı Britanya karar alıcılarının Avrupa bütünleşmesi konusunda istisnacılık söylemleri ve politikalarını benimsemelerine ve nihayetinde Britanya'nın Schuman Planı dışında kalmasına katkıda bulunduğu belirtilmektedir.

Anahtar Kelimeler: Schuman Planı, Britanya Muhafazakâr Partisi, Britanya Isş̧̧i Partisi, hasımlık, istisnacılık

\section{Introduction}

The old continent, Europe, was unable to keep up with the economies of USA and USSR after the Second World War. Its economic fate was in the hands of the former as one of the emerging superpower of the time. In order to achieve the continent's survival, European integration was seen as a cure to the problem by some European nation states. Because divided Europe was not only the reason of war and weak economy but also "the ultimate threat" for the future ${ }^{1}$. In other words, referring to Alan Milward's conceptualization, integration would be the rescuer of the nation states in Europe ${ }^{2}$.

In addition to the realities of post-war period, a united Europe ideal had been in the mind of some intellectuals and politicians since the end of First World War. Briand Plan, Organization for European Economic Cooperation, Council of Europe ${ }^{3}$ were some of the attempts to achieve it, yet none of them could get as close as Schuman Plan. Therefore, 9 May 1950 was a milestone in the history of European integration when the French Foreign Minister Robert Schuman proposed the pooling of French and West German supplies of coal and steel; and made an invitation to other European states willing to be involved in this plan. Given the peril of nationalism after the Second World War, the proposal was designated as a supra-national authority which would manage the pooling. This supra-national body, aka High Authority, would be able to limit the economic sovereignty of participant nation states and independent of governments. The invitation made by French Government did not necessitate the acceptance of supra-nationalism in advance for the involvement in detailed talks, but it demanded that no other alternative mechanism to be discussed in the conference table ${ }^{4}$.

\footnotetext{
${ }^{1}$ Hörber 2006, p. 209.

${ }^{2}$ Milward 1992.

${ }^{3}$ For a detailed analysis of these institutional attempts; Dinan 1999; Dedman 1996; Urwin 2014.

${ }^{4}$ Lord 1998, p. 25.
} 


\section{"Broker or brakeman?": An Analysis of Parliamentary Debates on Schuman Plan between British Labour and Conservative Parties}

Britain, as one of the invited European state, was informed in the same day of the announcement of the plan according to British Foreign Office. Schuman, on the other hand, expressed his willingness for British participation, yet mentioned his awareness regarding the psychological and technical difficulties that Britain could have while answering journalists' questions. For him, even if Britain did not participate, she could conform to the new environment after having realized the success of the proposal. Schuman's concern proved itself in the meetings and exchange of notes between French and British officials which lasted until 3 June when France declared the impossibility of any progress given the existing contradictory standpoints of two sides $^{5}$, while at the end of the May, Britain had already declined to join to detailed talks. Therefore the related conference on Schuman Plan started on 20 June in Paris, without British participation. However, opposition party of the time in Britain, Conservative Party, brought the issue to the House of Commons on 26 June with a motion calling the Labour Party government to involve in the negotiations. The Prime Minister Attlee replied this move with an amendment to the motion expressing British inability to join and after a two day long debate; it was the government's amendment which was accepted by majority. This process was followed by signature of Paris Treaty in 1951, again without British participation, in which Schuman's proposal was realized and European Coal and Steel Community (ECSC) ${ }^{6}$ was created symbolizing the first step towards European Economic Community (EEC) and today's European Union (EU).

Out of this historical decision of Britain, there emerged significant amount of studies evaluating Attlee government either by criticising with "missing the bus/boat" metaphor or by praying it as the decision was right and timely. From the first side, according to Deighton, due to its disdain towards the continent and fear of losing sovereignty which were shared by both Labour and Conservative Parties, Britain lost the initiative in Europe ${ }^{7}$. Another contribution coming from Dell, a former Labour Minister, argued that British decline for joining to negotiations was a failure which affected the whole of post-war history of the country ${ }^{8}$. Anthony Nutting also thought that it was the most significant chance that Britain missed to become leader of Europe ${ }^{9}$. In addition to these studies, Wurm made an important summary of this approach in his

\footnotetext{
${ }^{5}$ Sham and Younger 1967, p. 15-16.

${ }^{6}$ Paris Treaty was signed by France, West Germany, Italy, Belgium, The Netherlands and Luxemburg.

${ }^{7}$ Deighton 1990, p. 16.

${ }^{8}$ Dell 1995, p. 284.

${ }^{9}$ Nutting 1960.
} 
review article titled Britain and European Integration, $1945-63^{10}$. From the other side of the coin, Bullock and Young wrote that it was 1955-57 period $^{11}$ that could be named as "missed opportunity" rather than Schuman Plan decision ${ }^{12}$. Finally, according to Kaiser, Britain did not make a wrong decision as the non-involvement in Schuman Plan and ECSC did not harm the British economy ${ }^{13}$ and the same thought was shared by Gowland et $a{ }^{14}$ claiming that "the chequered history of the ECSC itself scarcely suggested that Britain had missed out on a opportunity".

Although these studies as a whole contributed to development of an academic field dealing with relations between Britain and Europe, the retrospective assumptions include "might-have-beens" as Wurm argued, and it seems hard to make these kinds of precise judgements ${ }^{15}$. Rather it would be better to focus on how Labour government made this decision and what forces shaped it to emerge as refusal? Therefore the framework chosen for this study is the British domestic politics itself, in particular the debates in parliament between the major political parties as the answers for above questions can mainly be found there. In short, the aim of this study is not to assess if the Schuman Plan was a missed chance or not, as plenty of studies did until now; but to analyse the effect of the relations between parties in British parliament on the decision not to participate in the Plan. Especially the debate and voting on 26-27 June was an evidence of tension between the two main parties of Britain and affected the result of non-participation to the conference on Schuman Plan. As a result, this study will be analysing the speeches made during two days and interpreting the nature of approach provided by MPs of both sides. The online archive of British Parliament, Hansard, will be the primary source for this analysis. In the following parts, reflections of Schuman Plan in the House of Commons will be examined firstly. Then the speeches will be categorized as non-participation decision and its possible results; and reasons of nonparticipation to show the adversary nature of both parties' stance. In the last part, there will be concluding remarks.

\footnotetext{
${ }^{10}$ Wurm 1998.

${ }^{11}$ This period refers to Messina Conference of 1955 and signature of Rome Treaty of 1957 establishing EEC. Britain also refused to join Messina Conference where the six countries involved in Schuman Plan decided to initiate a market "free from all customs duties and all quantitative restrictions". This attempt was institutionalized by the signature of Rome Treaty (Urwin, D.W.,2014: 89)

12 Bullock 1985. Young 1993.

${ }^{13}$ Kaiser 1996.

${ }^{14}$ Gowland et al. 2010, p. 34.

${ }^{15}$ Wurm 1998.
} 


\section{"Broker or brakeman?": An Analysis of Parliamentary Debates on Schuman Plan between British Labour and Conservative Parties}

\section{Reflections of Schuman Plan in the House of Commons}

Schuman Plan was brought to the agenda of British Parliament on 11 May by Prime Minister Attlee. According to him, it was a proposal with

"far-reaching implications for the future economic structure of participating countries; and this aspect will require very careful study by His Majesty's Government and the other Governments concerned. His Majesty's Government will approach the problem in a sympathetic spirit and desire to make it clear at the outset that they welcome this French initiative to end the age-long feud with Germany and so bring unity and peace to Europe" ${ }^{\text {. }}$.

This warm welcome was followed Churchill's demand for a debate as he and other Conservative MPs were asking for the details of the proposal. Since Attlee needed time to look into proposal and thought that it was early yet, there were no more debates followed on the issue in the House of Commons. Although there were some comments on the Plan in the discussions of other debate topics from the parliamentary agenda, the next comprehensive debate was held on 13 June. However this was the time when all the diplomatic exchange had already ended between France and Labour cabinet ${ }^{17}$. Therefore Prime Minister dedicated his time of the opening speech in the debate to explain the completed procedure of exchange. According to him, French Government was not clear how the proposal would work in practice and in theory, although they had already clarify pooling of the resources to a High Authority. Since his government did not want to give prior commitment, Britain neither accepted nor rejected the proposal and this was assumed as a substantial difference of approach by French Government. As a result of this, Britain would not participate to the talks which would begin on 20 June and "put forward any alternative proposal". By giving the "hope" of association with the Plan in the future, he concluded his remarks by reminding Britain's international responsibilities ${ }^{18}$.

Just after Prime Minister finished his speech, the opposition served the information of a statement issued by the National Executive Committee (NEC) of Labour Party on the same morning of the debate. That document which the opposition was talking about was one of the most well-known and contentious documents of British post-war history, "European Unity". In this document,

\footnotetext{
${ }^{16}$ Hansard, 11 May 1950, vol. 475 column 588.

${ }^{17} \mathrm{https}: / / w w w . c v c e . e u / e n / \mathrm{obj} / \mathrm{conclusions}$ of_a_meeting_of the cabinet_on_the refusal_to parti cipate_in_the negotiations_on_the_schuman_plan_london_2 june_1950-en-8737a230-69244905-8004-dee $4385 \mathrm{ad} 38 \mathrm{e} \cdot \overline{\mathrm{h}} \mathrm{tml}$ (accessed on 20 January 2018 )

${ }^{18}$ Hansard, 13 June 1950, vol 476, column 36-37.
} 
NEC was considering the supra-national attempts in Europe as anti-socialist and in order to preserve the national control over coal and steel industries Britain had to be out of this grouping as these industries were "central to the party's nationalization programme"19. This was interpreted as one of the most socialist document of British post-war history as NEC was embracing it as a prerequisite for further integration initiatives.

Although these discussions brought some main themes to the agenda of the House of Commons, it was the debate on 26-27 June when intense discussions emerged between government and opposition. This two-day long debate, despite the demand of some MPs to extend it, lasted approximately 10 hours in total and nearly 89000 words were used. This extensive debate took also the attention of press. The Economist, the weekly journal, had already declared its support for the Plan and belief in benefit of participation. On $1^{\text {st }}$ of July, it published an article titled "Broker or Brakeman?" In this article, the journal was trying to convince its reader that "it is the resemblance, not the differences, between the outlook of the Government and Opposition that are most striking". There was an evidence of unity on basic issues despite difference "on shades on emphasis and angles of approach". While both sides were supporting "three circles principle" 20 , the role in each one of the circles was a matter of dispute. Therefore it was a matter of decision of choosing who would be in the intersection of three circles: "Broker or Brakeman?"21.

The Economist's claim could be interpreted as a reminder of the "consensus" debate in British politics. First of all, by definition, consensus means "agreement on values and norms". Since it is associated with "moderation and reasonableness", it provides positive connotations. Consensus approach embraces the view that the post-war period in Britain "it is the massive continuity that stands out" ${ }^{\prime 2}$. As a legacy of war, consensus deriving from Keynesian political economy was "a set of commitments, assumptions and expectations...shared by the great majority of the country's political and economic leaders"23. Rose also argues that there are many similarities in policy preferences of Labour and Conservative Parties regardless of party ideology and rhetoric. Due to historical circumstances and factors outside national control,

\footnotetext{
${ }^{19}$ Gowland et al. 2010, p. 33

${ }^{20}$ It is a foreign policy doctrine firstly offered by Winston Churchill locating Britain at the intersection of three circles, as the symbols of Commonwealth, United States of America and Europe.

${ }^{21}$ The Economist July 1, 1950.

${ }^{22}$ Kavanagh 1992, p. 176-180

${ }^{23}$ Marquand 1988, p. 18.
} 


\section{"Broker or brakeman?": An Analysis of Parliamentary Debates on Schuman Plan between British Labour and Conservative Parties}

policies on inflation, economic growth, unemployment, distribution of wealth became examples of continuity until Thatcher period in British politics ${ }^{24}$.

Although consensus approach has a wide range acceptance in the studies of British politics, even the most ardent supporters can approve the differences of rhetoric between two parties. Especially, in parliamentary debates and party conferences, according to Kavanagh and Morris, it is on the surface. While Conservative Party preferred to use freedom of opportunity, sustainment of Britain's world leader position, promotion of enterprise and private property ownership in its political language, Labour's rhetoric was shaped around the terms such as "emphasised equality, economic planning, fairness, advancing the interests of working people and their families, and the multi-racial Commonwealth" ${ }^{25}$. Seldon also contributes this debate by reminding that consensus does not mean "total agreement between major parties on all aspects of policy". It is not an agreement on ideology and rhetoric. Post-war consensus should refer to "the nature of a fragile compromise" instead of a deep-rooted agreement $^{26}$.

As a result of this exceptional situation of rhetoric, consensus approach is criticized by the line of thinking that claims political system in Britain proposes the incentives to challenge the position of opposite party as the possibility of coalition is low. Dutton argues that consensus politics in Britain "was far from complete; it never became total" and adds that British political structure is shaped by adversarial rhetoric ${ }^{27}$. This approach basically embraces that "hostile rhetoric and verbal attacks bring electoral advantage" to the political parties. Especially, for the opposition party, it turns in to oppose everything the government is saying although it would change after assuming the office. According to Smith and Aspinwall, the issue of Europe is a particular field of policy where it has produced various adversarial cases between the main two parties in Britain. According to authors,

"Since the opposition party does not face the prospect of entering into coalition with the governing party, it will attempt to exploit definitive positions on issues to its political advantage. In the instance of Europe, these positions may be enthusiastically in favour of or rigidly opposed to further integration. Adversarialism operates in either case" 28 .

\footnotetext{
${ }^{24}$ Rose, 1980.

${ }^{25}$ Pimlott et al. 1989, p. 15.

${ }^{26}$ Coxall and Robins 1998, p. 50.

${ }^{27}$ Kavanagh 1992, p. 180.

${ }^{28}$ Smith and Aspinwall 2007.
} 
Therefore, government becomes open to any kind of rhetorical attack regardless of its position on European integration. As a solution to this, government might end up with a tentative stance for its European policy. On the one hand, if it fully supports Europe, opposition would be able to attack from the loss of sovereignty. On the other hand, it can not reject the alternatives of integration as it would be interpreted as isolation from the economic system of Europe and degradation of political influence.

In the light of the insight given by adversary model, the nature of parliamentary debate on Schuman Plan on 26-27 can be viewed more in line with a rhetorical hostility rather than consensus argued by The Economist. Onslow claims that during the debates Conservatives used the Plan only "as a stick with which to beat the Government". Widespread idea within the party was if Tories were in power, they would follow the same path with Labour. Because for a party that had opposed the nationalisation of steel and iron industries, it would be inacceptable to go in line with handing over the control of these industries to "a body outside British control" ". As a result, they were following a strategic path that might lead to an electoral gain for the next election, although what they were supporting was not in line with traditional Conservative policy.

Labour, on the other hand, was also reluctant to appreciate the opposition's initiative as it had already declined the invitation and was seeking to be the sole authority on foreign policy issues. Because, Churchill's involvement in foreign policy issues such as The Hague Congress and Council of Europe, Bevin's poor health condition and finally the loss of seats in February 1950 general election had shaken the party's authority. In order to regain its dominance, they needed to produce a particular and characteristic Labour approach and exceptionalist rhetoric would be serving to make their case legitimate and convincing. By this way both Conservative and Labour Party constituted two rival camps during the debate and even the consensus on issues such as peace, security and full employment did not help to get them closer. Therefore the following part of study was dedicated to analyse the differences in Schuman Plan stance of both parties within the context of, firstly, non-participation decision itself and its possible results; and secondly, the reasons of non-participation.

\section{Non-Participation and its Possible Results}

The first area that there was no consensus between the parties was actually the very nature of the issue: non-participation as it was the final

\footnotetext{
${ }^{29}$ Onslow 1997, p. 65-66
} 


\section{"Broker or brakeman?": An Analysis of Parliamentary Debates on Schuman Plan between British Labour and Conservative Parties}

decision of Britain until the date of debate. While the opposition demanded the government to join in talks of Schuman Plan with a motion they gave on 26 of June, government amended this motion in the same day by declaring the impossibility of involvement. To begin with the government's approach, it was insisting on not to take part even in the conference in which details of the proposal would be discussed. In the amendment to the motion given by opposition, Labour Government was declaring their non-involvement "in the international consideration of his [Schuman's] proposals" ${ }^{30}$. Therefore, since there would be a voting of two conflicting motion and amendment at the end of the speeches, the debate was giving the signal of adversarial politics by the nature of legislature and decision making. According to Cripps, the Chancellor of Exchequer, who proposed the amendment to the House, France was expecting "unity of view" even at the level of negotiations and since it could not be established between British and French officials, "it was no good" to involve. For him, one of possible results of wrong decision of participation had already been declared to French Government by saying;

"an unhappy situation would arise if, having bound themselves to certain principles without knowing how they would work out in practice, they were to find themselves, as a result of the discussion, compelled to withdraw from their undertakings" ${ }^{31}$.

Moreover, it could have been destructive for the initial agreement between France and Germany, if Britain

"had entered into the negotiations and insisted...upon discussing not how to put into operation the principles but whether the principle, for instance, of the new high authority with supra-national powers was or was not acceptable" 32 .

By this way, Labour government was claiming that Britain, by declaring its non-involvement from the beginning, saved not only itself from an undesirable situation but also the future of Franco-German relationship. With this rhetoric, the government was trying to construct an image of Britain showing its grace and mercy for European states in need.

Opposition, on the other hand, believed in the benefit of being represented in the discussions at least. Wording of the motion was prepared carefully as the party did not want to be seen fully supporting the Schuman Plan ${ }^{33}$. However, direction of MP's speech was changing towards to

\footnotetext{
${ }^{30}$ Hansard, 26 June 1950, vol 476, column 1933.

${ }^{31}$ Hansard, 26 June 1950, vol 476, column 1937.

${ }^{32}$ Hansard, 26 June 1950, vol 476, column 1937.

${ }^{33}$ Onslow 1997, p. 65.
} 
participation to the Plan itself at some point and this was clear even in Eden's opening speech:

"Would we be prepared to enter discussions as a result of which a high authority would be set up whose decisions would be binding upon the nations who were parties to the agreement? My answer to that question would be, yes, provided...that we were satisfied with the conditions and the safeguards" ${ }^{\prime 34}$.

In addition to Eden's stance, some other Conservative MPs were also directly supporting the Plan, such as Edward Heath, who made his maiden speech during the debate. According to future Prime Minister Heath and the one realizing the accession of Britain to EEC:

"...magnanimity in politics is not seldom the truest wisdom. I appeal tonight to the Government to follow that dictum and to go into the Schuman Plan to develop Europe and to co-ordinate it in the way suggested"35.

As opposed to government's "grace and mercy" in the case of not joining to Schuman Plan's discussions, opposition were using rhetoric of "threat". Given the environment of Cold War, it was, first of all, Soviet Russia that could be brought the agenda of the House. Fitzeroy Maclean, Lancester MP of the Conservative Party, was arguing that Russians

"hate the idea of this country going in on the Schuman Plan... Why are the Russians showing this sudden concern for our welfare? Why are they so anxious that we should keep out of the Schuman Plan? It is because they realise -and I wish I thought Members opposite realised it- the immense political, economic and, above all, strategic importance of this issue. It is because they realise that in British participation in the Schuman Plan lies our best hope of a genuinely united Europe, a Europe strong enough to be an effective barrier to any further expansion or aggression on their part in the West. That is why they are against it" ${ }^{36}$.

Conservative Party leader, Churchill had already criticized Soviet ideology in 1920 by claiming it was "a pestilence more destructive of life than the Black Death or the Spotted 'Typhus",37. Labour government, on the other hand, kept its distance towards Soviet Union despite its claims of being a "socialist" party. According to Foreign Minister Bevin informing his cabinet in 1948 ,

"not only is the Soviet Government not prepared at the present stage to co-operate in any real sense with any non-Communist or non-Communist

\footnotetext{
${ }^{34}$ Hansard, 26 June 1950, vol 476, column 1916.

${ }^{35}$ Hansard, 26 June 1950, vol 476, column 1964.

${ }^{36}$ Hansard, 26 June 1950, vol 476, column 2034-2035.

${ }^{37}$ Warner 1996, p. 294
} 


\section{"Broker or brakeman?": An Analysis of Parliamentary Debates on Schuman Plan between British Labour and Conservative Parties}

controlled Government, but it is actively preparing to extend its hold over the remaining part of continental Europe and, subsequently, over the Middle East and no doubt the bulk of the Far East as well. In other words, physical control of the whole World Island is what the Politburo is aiming at- no less a thing than that" ${ }^{\prime 38}$.

These negative Soviet perceptions of the two main political parties were reflecting on the public opinion. Results of a poll from 1948 was showing that "no less than 91 percent of Britons believed that the Soviet Union wanted to dominate the world, compared with only 38 per cent of Italians and 30 per cent of French people" ${ }^{\prime 39}$. Therefore Conservative Party was confidently using Soviet threat argument in the debate on Schuman Plan to knock the government out.

Not just Soviet Russia but also the Germans could be a source of threat in the case of rejection of Schuman Plan according to David Eccles, Conservative MP for Chippenham. It was just after five years since the end of Second World War and Germany was still an issue of concern in the minds of British people. Therefore, it could be a convincing argument to get support for the motion. Eccles was basically saying that:

"There is no advance towards a stable peace and security at the same rate as Germany and Russia seem to be growing stronger. It is this anxiety to prevent another war that accounts for the astounding welcome given to the Schuman plan.... That is why the British refusal to enter these talks was and is utterly incomprehensible to the restless and nervous millions living between us and the Iron Curtain" 40 .

Some Conservatives were also underlining that even without the emergence of potential threats, Schuman Plan, in contrast to Labour party's stance, would fail after British non-participation by being replaced by FrancoGerman cartel and this time Franco-German rapprochement was seen as a threat to British interests.

\subsection{Dutch Problem}

The Netherlands had made a reservation before they accepted to take part in discussions of the Plan. This issue was referred in the motion given by opposition. For Conservatives, if Dutch Government could raise its reservation to go back on the condition that Plan was not working for the interest of the country, there would be no obstacle for Britain to do the same. However the Dutch case was not interpreted in the same way by the two parties.

\footnotetext{
${ }^{38}$ Warner 1996, p. 306

${ }^{39}$ Warner 1996, p. 306

${ }^{40}$ Hansard, 26 June 1950, vol 476, column 1970.
} 
For Labour Party, following the Dutch example "to incite the Government" was "pathetic" 41 . Trade volumes and partners of Britain and the Netherlands were even incomparable. Moreover, it was a risk taking according to the Chancellor and these risks would not create same effects for different scale of economies. At the end of the day, it was acceptable for Dutch government to take related risks.

"I can easily understand the Netherlands Government being prepared to take a risk in view of the small part of their economy that will be affected and accepting the principle without knowledge as to how it was to be applied or whether it could be applied, but I could not understand any British Government taking that risk with a major part, indeed, it may almost be said with the whole, of its economy at stake"42.

Cripps was also underrating the scale of economy in the Netherlands with below words:

"It is one thing to contemplate the possibility of the withdrawal of a Government responsible for only one-fortieth of the coal production and $1 / 150$ th of steel production and quite another to risk the withdrawal on this basis of a country with one-half of the coal and one-third of the steel production. The two cases are not comparable"43.

Belittling the scale of economy was an important tool of exceptionalist discourse for British foreign policy. A few months after Schuman Plan debates in the House of Commons, Prime Minister Attlee, this time, would be arguing that Britain was not "a simple Luxembourg". At the end, "these small countries" were all saved politically and economically by Britain in the war. Therefore they could not be taken as an economic and political model ${ }^{44}$.

However, for opposition, Dutch case was a safeguard for Britain and safeguards were the power that would shape, guide and judge the Schuman Plan. By this way, opposition was leaving no room for the will of other countries taking part in the Plan. Moreover, safeguards were so omnipotent in the eyes of Conservatives that they were enough to convince them for the abrogation of national sovereignty. As opposed to Dutch example speeches of Conservatives, Onslow argued that, many party members did not like the Dutch analogy idea, privately, as the Netherlands were already happy with a federal alternative. Therefore motion was implying for the public the acceptance of

\footnotetext{
${ }^{41}$ Hansard, 26 June 1950, vol 476, column 2026

${ }^{42}$ Hansard, 26 June 1950, vol 476, column 1939.

${ }^{43}$ Hansard, 26 June 1950, vol 476, column 1938.

${ }^{44}$ Black 1994, p. 236
} 


\section{"Broker or brakeman?": An Analysis of Parliamentary Debates on Schuman Plan between British Labour and Conservative Parties}

supra-national character of the Plan which was a departure from traditional Conservative policy ${ }^{45}$.

\section{Reasons of Non-Participation}

The reasons of Labour government's decision of non-participation were also a major tension between two parties. From Labour side; first of all, it was the prominence of coal and steel industries. These industries were so immense that other states could "gang up" against Britain and this could increase the prices. Opposition, on the other hand, was accepting importance of these industries to a certain extent. Yet it could be temporary, according to Conservative MP Colonel Claude Lancaster:

"Before the war, we were on the whole rather expensive steelmakers, and we produced coal somewhat more cheaply than on the continent. Today the position is reversed. We are producing steel more cheaply than on the continent, and we are producing coal more expensively. We are confronted with this problem: If we stand outside these conversations and plan,...it will have the effect of squeezing us out of our traditional European markets" ${ }^{\text {"46. }}$.

In other words, recovery of European markets was fast and Britain needed to take necessary precautions by joining to Europeans. Moreover, even these temporary advantages of British coal and steel industry would not be a priority and comprehensible within the context of Cold War situation.

Secondly, impossibility of consensus on the concepts of high authority, supra-nationalism and federalism led to another line of adversarial approach between Labour and Conservatives. For Labour, the binding nature of high authority was one of the biggest concerns. It was something not natural but "invented". Labour MP James Carmichael was expressing that;

"The French say that before the conference begins we have to accept the idea of a high authority, an authority standing above the governments of the countries participating. That is the first thing, and therefore our Government have laid it down... why they refuse to enter a conference which accepts the idea of a high authority standing above governments" ${ }^{\prime 4}$.

As the above quotation would tell us, high authority as referring the condition of being above the governments, supra-national could either be an adjective of high authority or a synonym for it and it was an indispensable part of the Schuman Plan. Basically, according to Labour party, "Everything is

\footnotetext{
${ }^{45}$ Onslow 1997, p. 66

${ }^{46}$ Hansard, 26 June 1950, vol 476, column 2010.

${ }^{47}$ Hansard, 26 June 1950, vol 476, column 2031.
} 
vague in the Schuman Plan, except one thing, the supra-national authority"48. In addition, due to this vagueness, it was normal to have reluctance towards this new institutional structure because there was no similar one until then as all other institutions that Britain was part of had international character which meant national governments could have the last word on decisions.

According to Labour Party, federalism was another concept that supranationalism had to be identified with. It could be the inevitable result of an institution under the rule of High Authority. Since France was in favour of federalism as a country lacking of self-confidence, it was better to inform French Government in advance that "no responsible party in this country [Britain] is willing to undertake federal union within any foreseeable time"49. Knowing that the concept of "federalism" could get a negative reaction from the Conservative benches, the government kept using it as a potential threat and natural consequence of involvement in the Schuman Plan. The decision of rejection was related with the perception of both for supra-nationalism and federalism at the same time.

However, Conservatives approached High Authority issue in a moderate even sometimes supporting way. For them, Britain had already abated its ideas on sovereignty. Given the conditions of memberships in Atomic Energy Commission under UN, OEEC etc., it would not be hard to accept the existence of High Authority under Schuman Plan. Moreover the ambiguity on the term could not be a reason of rejecting involvement in the talks. In this line, Conservative MP Julian Amery was arguing that;

"we cannot object to it on the ground of its powers until we have discussed them and contributed to their formation because we do not know what they will be. We cannot object to the question of to whom it will be responsible because that is not yet decided.... It seems to me to be very unwise to reject a thing out of hand when we do not know what it is" ${ }^{\prime 50}$.

Federalism, on the other, was something different than supra-nationalism and existence of High Authority according to Conservative Party, but even if Europe was trying to achieve this ideal, Britain, according to leader of the opposition, Churchill, would be there to

"favour and help forward all developments on the Continent which arise naturally from a removal of barriers, from the process of reconciliation, and

\footnotetext{
${ }^{48}$ Hansard, 26 June 1950, vol 476, column 2037.

${ }^{49}$ Hansard, 26 June 1950, vol 476, column 2041.

${ }^{50}$ Hansard, 26 June 1950, vol 476, column 2017.
} 


\section{"Broker or brakeman?": An Analysis of Parliamentary Debates on Schuman Plan between British Labour and Conservative Parties}

blessed oblivion of the terrible past, and also from...common dangers in the future and present" ${ }^{\prime \prime 1}$.

Because at the end of the day it was the Labour government's hostility that led to "tiresome and pedantic" approach of Schuman's insistence on surrender of sovereignty and this was a belief shared also by The Economist.

Thirdly, Britain's role in Commonwealth, Empire and Atlantic triangle was another topic that was brought to agenda of the debate. Labour Party, during this debate, became the ardent supporter of relations with Commonwealth by putting it in front of all other developments in Europe. It was also reminding the distinctive and exceptional position of Empire and Commonwealth. Supporting Schuman Plan and safeguarding the relations with Commonwealth were not compatible at all, especially when the strategic industries were at stake. Chancellor Cripps was arguing that;

"Our special trading relationships with the Commonwealth and Empire must likewise be greatly affected by the conduct of these two basic industries. Not only so, but the location and distribution of these industries in Western Europe are matters of the highest strategic importance" ${ }^{p 2}$.

Moreover, Government was thinking that previous examples on integration as British initiatives did not create an obstacle for the conduct of relations with Commonwealth; Chancellor was also adding that;

"Throughout all this period of intense intra -European activity, we have been able to carry the Commonwealth with us, and we have not in any way sacrificed the interests of the Commonwealth to those of Europe- nor have we done the reverse. It will be a bad day for everyone if it is ever sought to set intra-European interests against those of the Commonwealth"53.

On the other hand Conservative Party, traditionally accepted as the party of Empire and related relations, was following a different path during debates. First of all, it was claimed by Conservative MP Robert Boothby that;

"there was no responsible European statesman at Strasbourg who did not believe and declare that the Commonwealth must be closely associated with European union at every stage. They know perfectly well that without the Commonwealth and without their own overseas associated territories, Western Europe can never hope to be viable either politically or economically"54.

Moreover, involving in the discussions of Schuman Plan was not against the interest of Commonwealth and Empire. Yet despite this assumed trust in

\footnotetext{
${ }^{51}$ Hansard, 27 June 1950, vol 476, column 2157.

${ }^{52}$ Hansard, 26 June 1950, vol 476, column 1934.

${ }_{53}$ Hansard, 26 June 1950, vol 476, column 1947.

${ }^{54}$ Hansard, 27 June 1950, vol 476, column 2120.
} 
relations, opposition could not stop questioning government if they had consulted to Commonwealth states before taking the decision of nonparticipation. Another aspect of the issue was the ongoing problems in trade relations with Commonwealth. Some Conservative MPs reviewed the matter and found the solution in Schuman Plan. One of them was Julian Amery concluding that;

"The truth is that the United Kingdom cannot provide today all the capital goods the Commonwealth requires. Nor is our market, great as it is, big enough to consume all the raw materials, or all the foodstuffs, which the Commonwealth can, or could, produce. These domestic limitations of our own impose a certain limit, for the moment, on the development of the Commonwealth; but if, by participation in a plan such as M. Schuman has adumbrated, we could somehow direct some of the productive power of the Ruhr and French industry to the development of the Commonwealth and the Colonial Empire" ${ }^{\text {"55 }}$.

Opposition was also emphasizing the generosity of Europe that was in need of integration. If Britain would share the possible difficulties due to Commonwealth bonds, Europe would be ready to "do their best to meet them" $" 56$.

Finally, it was the ideological connotations that shaped the stance and rhetoric of two parties and there was no clear sign of consensus on this matter either. Socialism was one of the key concepts in this matter. Since "European Unity" document was newly emerged, government was carrying "the burden" of the arguments in it to the debate. What Labour government was doing during the debate is to vindicate socialism and show its contribution on European integration. Arthur Irvine, Labour MP for Liverpool Edge Hill, was claiming that;

"In this country today we have a Labour Government, recently returned after four and a half arduous years of office, recently returned with the support of a party which received two million more votes than any other party in the country. That is a fresh mandate to the Labour Party which believes that the solution to this problem of integrating European industry and production is a Socialist solution" $" 57$.

For Labour party, socialism was also directly related with democratic procedure that was something missing in Schuman Plan structure. High Authority meant giving up parliamentary democratic values of Britain. As

\footnotetext{
${ }^{55}$ Hansard, 26 June 1950, vol 476, column 2021.

${ }^{56}$ Hansard, 26 June 1950, vol 476, column 1977.

${ }^{57}$ Hansard, 26 June 1950, vol 476, column 2013.
} 


\section{"Broker or brakeman?": An Analysis of Parliamentary Debates on Schuman Plan between British Labour and Conservative Parties}

opposed to the concept of democracy which was provided by socialist government of the country thanks to the nationalization of industries, high authority would not have democratic responsibility and would be an example of "oligarchy imposed on Europe...with arbitrary power and enormous influence ${ }^{95}$. Instead of following these alternatives proposed by Schuman Plan, Europe would have to find the only answer for unity within the framework of socialism. Irvine was also proposing that;

"There is only one fundamental and effective solution to the problem of the development of European economic unity, and that is the Socialist one. The ideal chance of solving the great problem which exists in developing European unity would come by the co-operation of like-minded Socialist Governments" 59 .

Interpretation of socialism in Conservative Party in relation to Schuman Plan was totally different. Socialism was one of the important reasons that the government stand aside of the Plan and it was offering everything opposite to necessities of integration. In the view of David Eccles;

"British Socialists are next to Communists in rejecting international arrangements for full employment. The Socialist Government relies upon physical controls, bilateral treaties, exchange control, and so on"60.

Moreover it was the source of isolationism and nationalism. This insular socialism of Labour Party led to nationalisation and nationalism to go hand in hand. Although the Opposition was not against the policy of full employment and believed that Schuman Plan would be helping to reach this aim, nationalisation policy of government was inacceptable and could not be a cause not to be involved in the talks. In line with Conservative's ideological criticisms, The Economist was also reminding the suspicion for the Government's pretext of "wider responsibilities and commitments" to serve for its isolation and socialism.

\section{Conclusions}

The article published on The Economist was a reflection of journal's call for Britain to join Schuman Plan. By claiming the consensus between the two parties, the journal was trying to establish a common ground and imply a positive connotation on the idea of Schuman Plan. Moreover it was offered as the moderate and reasonable alternative to British decision makers. However as it was analysed above, parliamentary debates on Schuman Plan were a strategic clash of Conservative and Labour Parties. The decision of non-participation,

\footnotetext{
${ }^{58}$ Hansard, 27 June 1950, vol 476, column 2107.

${ }^{59}$ Hansard, 26 June 1950, vol 476, column 2013

${ }^{60}$ Hansard, 26 June 1950, vol 476, column 1973.
} 
reasons and possible effects of it were all a matter of conflict. In addition, the nature of voting for the motion and amendment created polarization in the House of Commons, because at the time of the debate, British parliament was working with the function of not just consultation, but also decision making.

On the other hand, party positions during the debates were not emphasizing the traditional party lines. Labour Party prioritising Commonwealth and Empire as opposed to internationalism emphasized by Conservative MPs as a gift of European integration could only be examples of constructed strategy within the context of adversarial approaches of each party. While the government was trying to gain its authority back in foreign affairs, the opposition was there to just oppose and create an electoral advantage given the fact that the majority of Labour Party was only five in the parliament.

Last, but not least, adversarial nature of the debate sometimes created an exceptionalist rhetoric during the debate, especially in Government's speeches as it was pushed by the Opposition to take a clear stand against Europe and exceptionalism could be appreciated in the eyes of public even if the decision of non-participation was not wholeheartedly embraced. 


\section{“Broker or brakeman?": An Analysis of Parliamentary Debates on Schuman Plan between British Labour and Conservative Parties}

\section{BIBLIOGRAPHY}

\section{A. Primary Resources}

Hansard, 11 May 1950, vol. 475 column 588.

Hansard, 13 June 1950, vol 476, column 36-37

Hansard, 26 June 1950, vol 476, column 1916.

Hansard, 26 June 1950, vol 476, column 1933.

Hansard, 26 June 1950, vol 476, column 1934.

Hansard, 26 June 1950, vol 476, column 1937.

Hansard, 26 June 1950, vol 476, column 1938.

Hansard, 26 June 1950, vol 476, column 1939.

Hansard, 26 June 1950, vol 476, column 1947.

Hansard, 26 June 1950, vol 476, column 1964.

Hansard, 26 June 1950, vol 476, column 1970.

Hansard, 26 June 1950, vol 476, column 1973.

Hansard, 26 June 1950, vol 476, column 1977.

Hansard, 26 June 1950, vol 476, column 2010.

Hansard, 26 June 1950, vol 476, column 2013.

Hansard, 26 June 1950, vol 476, column 2017.

Hansard, 26 June 1950, vol 476, column 2021.

Hansard, 26 June 1950, vol 476, column 2026

Hansard, 26 June 1950, vol 476, column 2031.

Hansard, 26 June 1950, vol 476, column 2034-2035.

Hansard, 26 June 1950, vol 476, column 2037.

Hansard, 26 June 1950, vol 476, column 2041.

Hansard, 27 June 1950, vol 476, column 2107.

Hansard, 27 June 1950, vol 476, column 2120.

Hansard, 27 June 1950, vol 476, column 2157.

\section{B. Secondary Resources}

Black 1994

Bullock 1985

Coxall and Robins 1998

Jeremy Black, Convergence or Divergence?: Britain and The Continent. London: Macmillan.

Alan Bullock, Ernest Bevin. Foreign Secretary 1945. Oxford: Oxford University Press.

Bill Coxall and Lynton Robins, British Politics Since the War. London: Macmillan Press.

Dedman 2006
Martin Dedman, The Origins and Development of the European Union 1945-1995: A History of European Integration. Routledge, London-New York. 
Deighton 1990

Dinan 1999

Gowland et alii 2010

Hörber 2006

Kaiser 1996

Kavanagh 1992

Lord 1998

Marquand 1988

Milward 1992

Nutting 1960

Onslow 1997

Pimlott et alii 1989

Rose 1980

Anne Deighton, "Missing the boat: Britain and Europe 194561", Contemporary British History, 3(3), p. 15-17.

Desmond Dinan, Ever Closer Union: An Introduction to European Integration. Basingstoke, United Kingdom.

David Gowland, Arthur Turner and Alex Wright Britain and European Integration Since 1945 On the Sidelines, London: Routledge

Thomas Hörber, The Foundation of Europe: European Integration Ideas in France, Germany and Britain in the 1950s. Heidelberg: VS Verlag für Sozialwissenschaften

William Kaiser, Using Europe, Abusing the Europeans: Britain and European Integration, 1945-63. London: Macmillan.

Denis Kavanagh, "The Postwar Consensus", Twentieth Century British Politics, 3(2), p. 175-190.

Christopher Lord, "With, but not of: Britain and Schuman Plan, a Reinterpretation". Journal of European Integration History, 4(2), p. 23-46.

David Marquand, The Unprincipled Society. London: J.Cape

Alan Milward, The European Rescue of Nation State. London: Routledge.

Anthony Nutting, Europe will not Wait. London: Hollis \& Carter.

Sue Onslow, Backbench Debate within the Conservative Party and its Influence on British Foreign Policy, 1948-57. London: Macmillan Press.

Ben Pimlott, Denis Kavanagh and Peter Morris, "Is the 'the postwar consensus' a myth ?" Contemporary Record, 2(6), p. 12-15.

Richard Rose, Do parties make a difference? London: The Macmillan Press

Sham and Younger 1967

Ulrich Sham and Kenneth Younger, "Britain and Europe, 1950", International Affairs, 43(1), p. 12-24.

Smith and Aspinwall 2007

Mitchell Smith and Mark Aspinwall, "Institutions and Ambivalence: Party Management, Adversarialism and British Policy Toward Europe", Current Politics and Economics of Europe, 19(3-4), p. 233-250.

The Economist July 11950 
“Broker or brakeman?": An Analysis of Parliamentary Debates on Schuman Plan between British Labour and Conservative Parties

The Economist , "Broker or Brakeman?" July 1, 1950; p. 3; Issue 5575.

Urwin 2014

D. W. Urwin, The community of Europe: A history of European integration since 1945, Routledge.

Warner 1996

Geoffrey Warner, “From 'Ally to Enemy: Britain's Relations with the Soviet Union, 1941-8" The Soviet Union and Europe in the Cold War, 1943-53, Palgrave Macmillan: London, p. 293-309

Wurm 1998

Clemens August Wurm, "Britain and European Integration,

Young 1993 1945-63", Contemporary Euroepan History, 7(2), p. 249-261. John W. Young, Britain and European Unity, 1945-1992. New York: Macmillan. 